\title{
Comparative Study of Soils Derived from Sedimentary and Basement Rock Formations of the Lower Ogun River Floodplain, South Western Nigeria
}

\author{
Elias P. O. ${ }^{1} \&$ Gbadegesin A. S. ${ }^{2}$ \\ ${ }^{1}$ Department of Geography, University of Lagos, Nigeria \\ ${ }^{2}$ Department of Geography, University of Ibadan, Nigeria \\ Correspondence: Elias P. O., Department of Geography, University of Lagos, Nigeria. Tel: 234-803-401-0411. \\ E-mail: pelias@unilag.edu.ng \& po_elias@yahoo.com
}

Received: March 2, 2012 Accepted: March 20, 2012 Online Published: May 18, 2012

doi:10.5539/jgg.v4n2p71 URL: http://dx.doi.org/10.5539/jgg.v4n2p71

\begin{abstract}
The anisotropic nature of soils makes it imperative to study the associations of soils and regional landscapes for sustainable land use planning and management. This paper examines soil properties involving four catenas on two parent rock formations in two ecological zones. It simultaneously studied the vertical and lateral variations of soil properties in relation to parent materials, slope positions and pedogenetic-geomorphic processes along hillslopes extending over basement complex and sedimentary rock formations of the Lower Ogun River Floodplain. The different parent materials from different parent rocks, slope positions and pedogenetic-geomorphic processes accounted for the intra-profile and inter-profile variations of topsoil and subsoil properties in the landscape. The study demonstrated that in a given hillslope, topsoil and subsoil properties show more significant differences $(\mathrm{p}<0.05)$ between diverse rock formations, distinct parent materials and different slope positions than within them. This suggests that the soils are genetically linked due to the influence of relief (differences in elevations) along the hillslope and geomorphic factors (parent materials) which affirms catenary associations of soils along the hillslopes.
\end{abstract}

Keywords: Lower Ogun River Floodplain, soil properties, basement rock, sedimentary rock, catena, geomorphic factors and processes

\section{Introduction}

Soil-landscape study is very significant in natural resource survey and management (Gessler et al., 1995). The study of soils in the landscape is very important for the understanding of the processes and patterns of soil development and properties. It also helps to account for the role of parent materials and slope positions on soil properties and processes along the hillslope. There is the need to study horizon-related movements of water and materials to understand the intra-profile differences within catenas as well as inter-profile removal and accumulation of materials along the catenas and between different landscapes spanning two geomorphic formations. In general, water and materials move from upper slopes to bottom slopes and from landscapes of higher elevations to lower elevations over catenas involving heterogeneous parent rock materials and ecological zones.

Soils are anisotropic in nature both in a vertical and lateral context. Previous studies have shown more evidence of vertical soil variation than the lateral difference (Wilding et al., 1994). This may be because more attention has been given to the vertical than the lateral variation of soil properties. In the present study, physical (depth to water table, horizon thickness, colour, and mottles) and chemical (calcium, magnesium, sodium, copper, iron, organic carbon, total nitrogen, available phosphorus, manganese, and $\mathrm{pH}$ ) properties of soils were analyzed to study their vertical and lateral variability in the landscapes.

The choice of Oyan site with basement complex rock and Mokoloki with sedimentary rock is to offer a good basis for comparing the interactions between soil forming factors and processes in a given physiographic region. The different parent materials from different parent rocks and geological formations (basement complex and sedimentary) on different landscape positions are the assumed spatial determinants of the variability of soil properties of Lower Ogun River floodplain. This also enhanced an examination of intra-profile and inter-profile 
variations of soil profiles of different transects in the landscape. The setting further provided information about soils in discontinuous drainage conditions which enhances the study of soil processes and properties as well as quality in the landscape. Park and Purt (2002) argued that the factors of terrain attributes, nutrient dynamics, erosion weathering and leaching influence soil processes, properties and quality in the landscape. The position of soil profiles at the upper, middle and bottom slopes in different transects also helped to describe the influence of slope positions on vertical horizonation, translocation and geomorphic processes in the landscape.

The goals of this study were: (i) to ascertain which soil properties are influenced by parent materials and slope positions; (ii) to characterize soil properties in response to pedogenetic-geomorphic processes along the hillslope over the basement complex and sedimentary rock formations, and (iii) to show the implication of the differentiation of landscape units and soil properties for sustainable land management. This study will therefore be very useful for sustainable soil sampling/mapping, assessment of soil properties and site-specific management practices in the landscapes (Tabi \& Ogunkunle, 2007; McBratney et al., 2000).

\section{Materials and Methods}

\subsection{Study Area}

The Lower Ogun River floodplain is located in southwestern Nigeria. Two sites were selected for the study, namely areas around the floodplains of River Oyan by the Dam and River Ogun around Mokoloki (Figure 1). The study sites were bounded by Oyo State in the north east, Republic of Benin in the north west and Lagos State in the south and were approximately located around $3^{\circ} 20^{\prime} \mathrm{E}$ and $7^{\circ} 15^{\prime} \mathrm{N}$ (Oyan Site) as well as $3^{\circ} 22^{\prime} \mathrm{E}$ and $6^{\circ} 52^{\prime} \mathrm{N}$ (Mokoloki Site). Oyan Site is North West of Abeokuta (Ogun State) with a distance of about $20 \mathrm{~km}$ from Abeokuta while Mokoloki is North East of Lagos State with a distance of about $15.5 \mathrm{~km}$ from Abeokuta. The first site is situated on basement complex rocks and the later on sedimentary rock units.

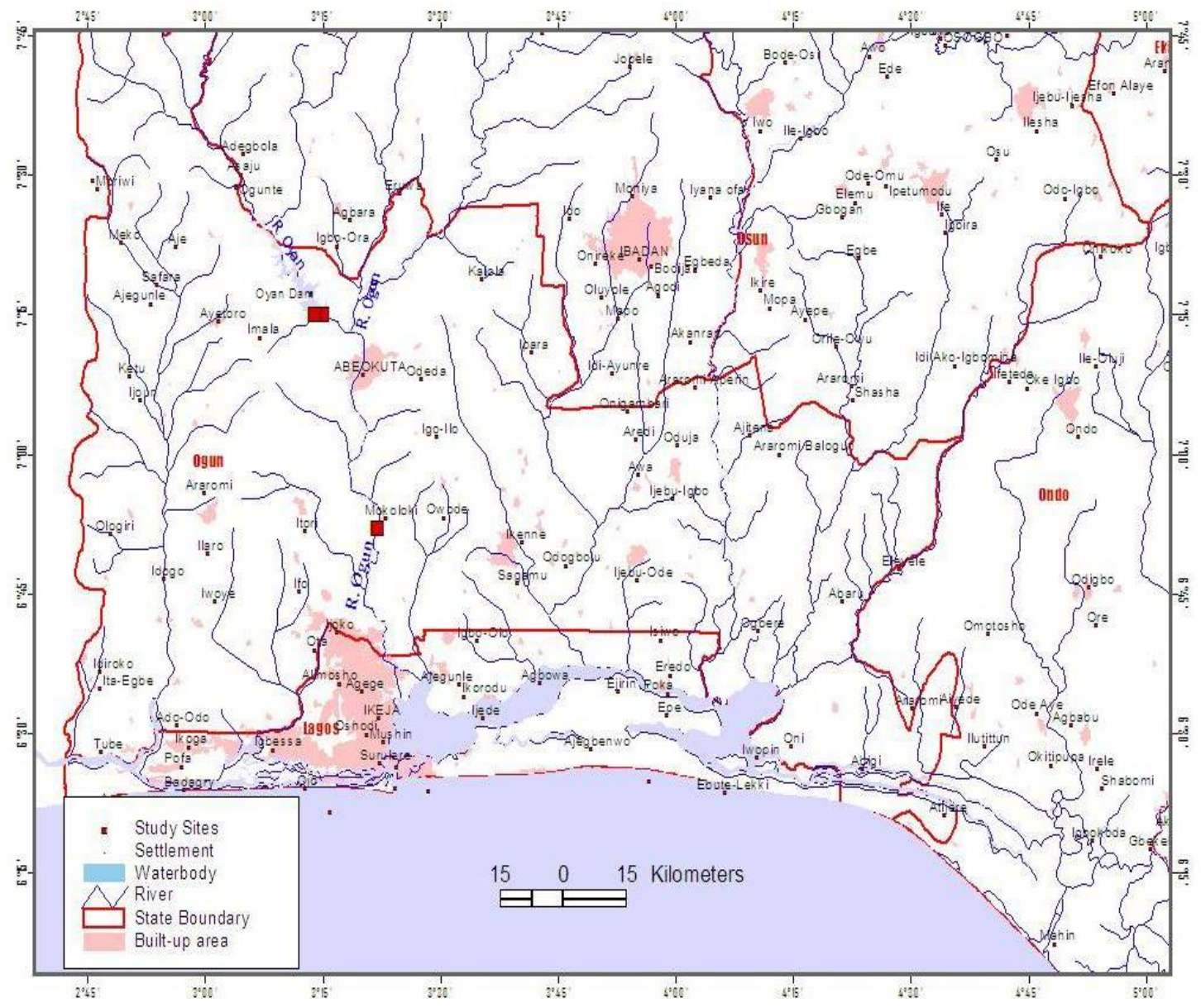

Figure 1. A section of southwestern Nigerian showing the location of the study sites 
The geology of Lower Ogun River floodplain is described as a rock sequence that starts with Precambrian basement (Jones \& Hockey, 1964) and consists of quartzites and biotite schist, hornblende-botite, granite and gneiss. The basement complex rocks are directly overlain by the Maestrichtian Sediments (Hurley \& Rank, 1976). They consist of such rock types as coarse-porphyritic hornblende-biotite-granodiorite, biotite-granite gneiss, pegmatite, porphyoblastic granite gneiss, amphibolite-schist, quartz-schist and banded gneiss (Kehinde-Phillips, 1992). The foliation and joints on these rocks control the course of the rivers, causing them to form trellis pattern, particularly to the north of the study area. On the other hand, the sedimentary rock sequences are from Cretaceous to recent formation consisting of grey sand intercalated with brown to dark grey clay.

The topography of the study area is generally low-lying undulating flat landform, but with some very rugged areas having scarp slopes and gorges. The relief is generally low, with gradient in the north-south direction. The elevation is even as low as between $17 \mathrm{~m}$ to about $73 \mathrm{~m}$ above sea level in some parts of Oyan River and Mokoloki, which constitute the study sites. The Ogun River is the major water body in the study area and takes its source from the Igaran hills at an elevation of about $530 \mathrm{~m}$ above mean sea level and flows directly southwards over a distance of about $480 \mathrm{~km}$ before it discharges into the Lagos lagoon. The Oyan River is the main tributary of the Ogun River, joining it from the west near the city of Abeokuta. The Lower Ogun River floodplain is of extremely low slope $(<$ $1 \%)$ characterized by flooding with marshes and swamps. The morphology of the river has entered the mature stage of river profile.

Generally, the climate of the study area is influenced by Northeast-Southwest movement of a zone of surface discontinuity between maritime (Atlantic) air masses and dry continental (Sahara) air masses (Ayoade, 2006). The study area has a humid tropical climate with characteristic wet and dry seasons. The rainy season is long, being about 9 to 10 months from March and lasts till October while the dry season starts from around October and ends in March. The Ogun River floodplain has a typical bimodal rainfall pattern with peaks in July and September. According to Ogun Osun River Basin Development Authority (2006), the mean annual rainfall is about $1040 \mathrm{~mm}$ at Oyan Dam, $1479 \mathrm{~mm}$ at Mokoloki and $1165.2 \mathrm{~mm}$ obtained from the closest weather station at Abeokuta. During the rainy months temperatures are maximum for good crop growth at $25^{\circ} \mathrm{C}$ (Ojanuga, 2006) and annual relative humidity is about $80 \%$ at Abeokuta. The soil temperature at Abeokuta varies with depth. For instance, the mean annual soil temperature at $5 \mathrm{~cm}$ is $35.5^{\circ} \mathrm{C}, 38.2^{\circ} \mathrm{C}$ at $10 \mathrm{~cm}, 31.7^{\circ} \mathrm{C}$ at $20 \mathrm{~cm}, 30.2^{\circ} \mathrm{C}$ at $30 \mathrm{~cm}$, $29.9^{\circ} \mathrm{C}$ at $50 \mathrm{~cm}$, and $29.9^{\circ} \mathrm{C}$ at $100 \mathrm{~cm}$. Sunshine hours in the growing season are less than in humid or sub-humid zones because of heavy cloud overcast, but values of about 6-7 hours per day can be adequate for good plant growth. The vegetation of the study area at Oyan site is forest-savanna mosaic and at Mokoloki site is a mangrove forest. The land use patterns in the study area are influenced by the predominant climate, vegetation, soil type and human activities. Thus, much of the land is used for mixed farming involving cropping and animal grazing in the agroecological zone especially around the floodplain with regular supply of forage and water for the cattles.

\subsection{Field Sampling}

The study employed stratified systematic sampling technique to examine soil variability within landscape units (Hammer, O’Brien, \& Lewis, 1987; Reese \& Moorland, 1996). Within each geological unit, two transects were selected representing the cultivated and fallow landscape sites. These represent the disturbed and undisturbed landscapes and served as basis for comparison of soil properties in different land use areas. The study sites ran from the upland to the lowland areas thus dividing purposely into three slope positions: upland, middle and bottom slopes. At the site around River Oyan, two transects were selected and standard soil profile pits (see Plate 1) were dug at the slope positions at the two transects down to $200 \mathrm{~cm}$ depth, except where indurated ironstones were encountered. Six soil profiles pits were described and sampled. Similarly, two transects around River Ogun at Mokoloki site were selected and standard profile pits dug at the upper, middle and bottom slope positions up to $200 \mathrm{~cm}$ except where water was found. Also, six soil profiles were excavated, described and sampled. 


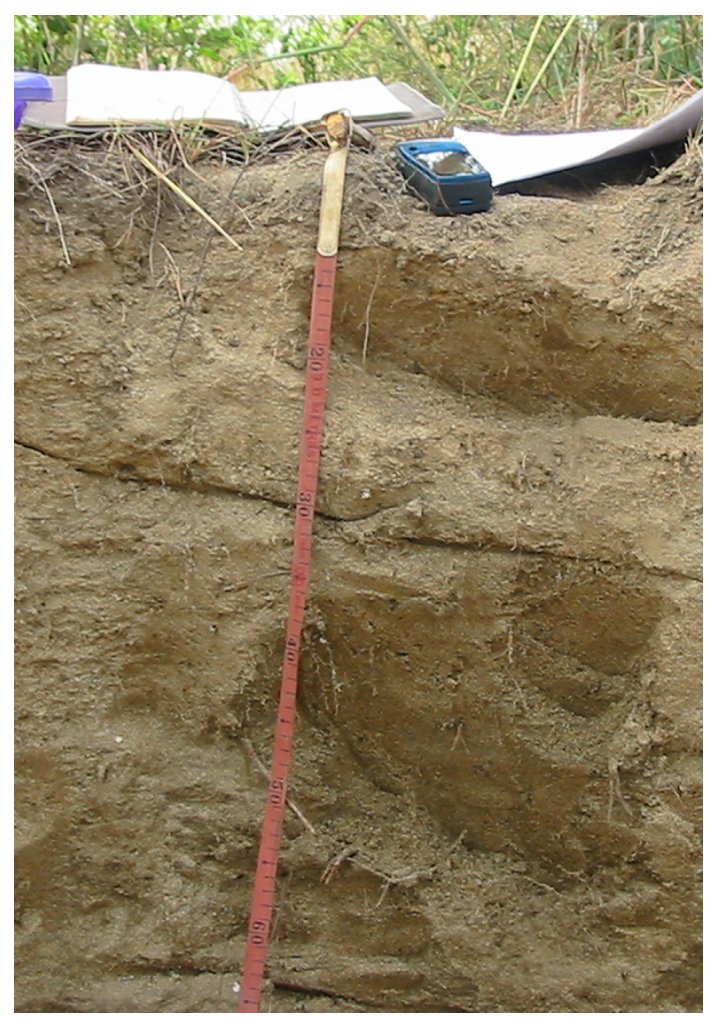

Plate 1. A typical soil profile pit (Loamy Sand Haplustalf) at the middle slope of the cultivated landscape of Oyan Site (Y2)

In each soil profile pit, identifiable horizons were sampled for description and labeled to facilitate laboratory analysis. This was very important to ascertain the quality of soil data used in the statistical analyses. Altogether, for the study area, a total of 12 soil profiles with 60 different horizon designations were described following the recommended procedure in the 'Guidelines for soil description' (FAO, 2006) and USDA(1999, 2003, 2006). Also, by using standard procedures, soil samples were collected from the identified horizons for laboratory analysis. The coding systems for the soil profiles, horizons and their geographic locations are presented in Table 1 below.

Table 1. Coding system and coordinates of the selected soil profiles

\begin{tabular}{|c|c|c|c|}
\hline Sites & Transect & Slope position & Soil Profile Pit \\
\hline \multirow{6}{*}{ 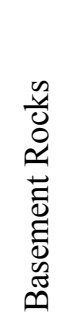 } & \multirow{3}{*}{ Cultivated } & Bottom & Y1 \\
\hline & & Middle & $\mathrm{Y} 2$ \\
\hline & & Upper & Y3 \\
\hline & \multirow{3}{*}{ Fallow } & Bottom & Y4 \\
\hline & & Middle & Y5 \\
\hline & & Upper & Y6 \\
\hline \multirow{6}{*}{ 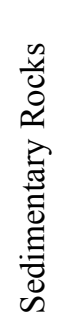 } & \multirow{3}{*}{ Cultivated } & Bottom & M1 \\
\hline & & Middle & M2 \\
\hline & & Upper & M3 \\
\hline & \multirow{3}{*}{ Fallow } & Bottom & M4 \\
\hline & & Middle & M5 \\
\hline & & Upper & M6 \\
\hline
\end{tabular}


Selected soil morphological, physical and chemical properties were measured and described. The morphological and physical characteristics described included colour, mottles, texture, consistency, concretions, and depth to water table were done in the field. These were used to describe the drainage pattern and erosional history of the study sites. The chemical properties included total nitrogen, organic carbon, phosphorous, exchangeable cations, micro-nutrients and $\mathrm{pH}$ which formed the basis for the soil quality and suitability analysis. Also included were data on general site characteristics such as geology, climate, slope, location, drainage, elevation, topography, vegetation, and land use.

\subsection{Laboratory Analysis}

The soil profiles were described, sampled and analyzed and then classified according to the guidelines in Smyth and Montgomery (1962) and Moss (1957) which described soils of basement complex and sedimentary rocks respectively in Southwestern Nigeria and according to USDA $(1999,2003,2006)$ as well as World Reference for Soil Resources (WRB, 2006). The FAO guidelines for Soil Description (FAO, 2006) were also used for the general soil description. Soil colour was described under field moisture condition using the Munsell soil colour charts.

To determine the grain size distribution, the soil samples were air-dried and crushed to pass through a $2 \mathrm{~mm}$ sieve. The proportion of gravel was taken as $>2 \mathrm{~mm}$ fraction. The fraction of sand was taken as $2.00-0.05 \mathrm{~mm}$, the fraction of fines was taken as $0.05-0.002 \mathrm{~mm}$, and the fines were further separated by hydrometer analysis which measures density of liquids involving a dry sample of soil treated with sodium hexametaphosphate to separate soil particles (Elliot et al., 1999). In determining the soil particle size distribution, a dispersing agent was mixed in distilled water until it completely dissolved. A dried soil sample weighing 50g poured into a container, a quantity of the dispersing solution and distilled water was then poured into the container and mixed thoroughly using a spoon which was rinsed off with distilled water after stirring. A meter stick was used to measure the distance the base of the graduated cylinder and the $500 \mathrm{ml}$ mark by putting the stick inside the cylinder. The initial temperature and hydrometer reading were recorded. The corrected temperature and hydrometer were obtained. The corrected hydrometer reading for the first reading is subtracted from the initial $50 \mathrm{~g}$ total soil in the sample and multiplied by 2 to obtain the exact percentage of sand. Similarly, the corrected hydrometer reading was subtracted from the second reading and multiplied by 2 to obtain the exact percentage for clay. Then the difference in percentage between the sum of percentage of sand and clay subtracted from 100 gives the exact percentage of silt. This was done for each sample of soil respectively to determine the percentage of sand, clay and silt in them.

The soil $\mathrm{pH}$ was determined in water (1:1 soil to water ratio) and in $1 \mathrm{~N}$ potassium chloride (1:1 soil to solution ratio) using a $\mathrm{pH}$ probe. The organic carbon was determined by the Walkley-Black method on soil samples reduced to $0.5 \mathrm{~mm}$ particle size (Juo, 1975, Walkley \& Black, 1934). Total nitrogen was analyzed using Kjeldahl method (Black, 1965). Available micronutrients (Cu, Zn, Fe and Mn) in soils were extracted with $0.1 \mathrm{~N}$ HCL acid and determined using atomic absorption spectrometer (AAS) (Black, 1965). Exchangeable cations were extracted with $1 \mathrm{~N} \mathrm{NH}_{4} \mathrm{OAC}(\mathrm{pH} 7.0)$. The cations ( $\mathrm{K}$ and $\mathrm{Na}$ ) in the filtered extracts were determined with a flame photometer while $\mathrm{Ca}$ and $\mathrm{Mg}$ were determined with atomic absorption spectrophometer (AAS). The exchangeable acidity in the soils was extracted with $1 \mathrm{~N} \mathrm{KCL}$ and titrated with $0.025 \mathrm{M} \mathrm{NaOH}$ (Mclean, 1965). The effective cation exchange capacity (ECEC) was the summation of exchangeable bases and acidity. Available P was determined by Bray-1 method (Bray \& Kurtz, 1945). The statistical analysis was done using Statistical Package for Social Sciences (SPSS) Release 12. The first step was to compute the means, coefficient of variation and standard deviation of the selected topsoil and subsoil properties which formed the independent variables. These were used to test the hypothesis that stated that there was no significant difference in the amount and concentration of topsoil and subsoil properties due to (i) influence of parent materials and (ii) slope positions. The Topsoil refers to $0-30 \mathrm{~cm}$ layers while subsoils are layers below $30 \mathrm{~cm}$ in depth. The parent materials identified are the alluvial and colluvial. The slope positions are the bottom, middle and upper slopes along the hillslopes.

\section{Results and Discussions}

\subsection{Soil Physical Properties}

The dominant soil texture of the basement complex rocks area are loamy sand or sandy loam underlain by a variety of alluvial or colluvial materials over coarse-grained granitic gneiss and pegmatities. The land surface is of the young, Holocene anthropogeomorphic epoch (Smyth \& Montgomery, 1962). The loamy sand covers about 70 percent of the land area at the bottom, middle and upper slope positions respectively. Water and material movements were however markedly influenced by the processes of colluviation along the catena. The soil 
moisture regime observed were aquic, typic, aeric, ultic and lithic. It was noteworthy that the morphology of the loamy sand soils, especially the stratification of the constituent materials, reflects both the parent rocks and pedogeomorphological processes.

The most common texture of soils found over the sedimentary rocks area are sandy clay or clay soils mantled by alluvial materials at the bottom slopes and colluvial materials at the middle and upper slopes. The land surface consists of ferruginous sandstones of the Eocene age (Moss, 1957). The age of the land surface is young anthropogeomorphic. Generally, the surface drainage is imperfect with moist and wet moisture conditions dominating the area. The moisture regimes were Aeric, typic, aquic or humic.

\subsection{The Influence of Parent Materials on Topsoil and Subsoil Properties}

Tables $2 \mathrm{a}$ and $2 \mathrm{~b}$ below show the variations in the mean values of sampled horizons of topsoil and subsoil properties of different parent materials of the study sites. The comparison of topsoil and subsoil properties of the Basement Complex rock indicate that none of the soil properties of the alluvial parent materials is significantly different $(p<0.05)$ whereas only $\mathrm{Ca}$ and organic carbon are significantly different $(\mathrm{p}<0.05)$ over the Sedimentary Rock unit. Similarly, the analysis of the topsoil and subsoil properties of the colluvial parent materials show that total Nitrogen and organic carbon are significantly different $(p<0.05)$ in the Basement Complex rock unit while only organic carbon is significantly different $(\mathrm{p}<0.05)$ over the Sedimentary Rock type. The topsoil and subsoil properties that are significantly different $(\mathrm{p}<0.05)$ may have been influenced by other pedogenetic-geomorphic factors like eluviation and illuviation other than lithological factor. However, the analysis to compare both topsoil and subsoil properties of alluvial and colluvial parent materials in both study sites without regards to ecological differences reveal that total nitrogen, organic carbon, $\mathrm{pH}$ and $\%$ clay are significantly different $(\mathrm{p}<0.05)$.

Table 2a. The physical and chemical properties of the topsoils and subsoils of the Alluvial parent materials. Figures are mean values for sampled horizons

\begin{tabular}{|c|c|c|c|c|c|c|}
\hline \multirow[t]{2}{*}{ Soil Properties } & \multicolumn{3}{|c|}{$\begin{array}{l}\text { Alluvial Parent Materials } \\
\text { Basement Complex Rock }\end{array}$} & \multicolumn{3}{|c|}{$\begin{array}{c}\text { Alluvial Parent Materials } \\
\text { Sedimentary Rock } \\
\end{array}$} \\
\hline & $\begin{array}{l}\text { Topsoil } \\
(\mathrm{n}=5)\end{array}$ & $\begin{array}{c}\text { Subsoil } \\
(\mathrm{n}=6)\end{array}$ & Sig.value & $\begin{array}{c}\text { Topsoil } \\
(\mathrm{n}=6)\end{array}$ & $\begin{array}{c}\text { Subsoil } \\
(\mathrm{n}=13)\end{array}$ & Sig.value \\
\hline $\mathrm{Ca}\left(\mathrm{cmol} \mathrm{kg}^{-1}\right)$ & 4.27 & 4.72 & 0.56 & 5.19 & 3.98 & 0.03 \\
\hline $\operatorname{Mg}\left(\mathrm{cmol} \mathrm{kg}^{-1}\right)$ & 0.11 & 0.16 & 0.07 & 0.16 & 0.13 & 0.21 \\
\hline $\mathrm{K}\left(\mathrm{cmol} \mathrm{kg}^{-1}\right)$ & 0.31 & 0.36 & 0.47 & 0.35 & 0.31 & 0.17 \\
\hline $\mathrm{Na}\left(\mathrm{cmol} \mathrm{kg}^{-1}\right)$ & 8.23 & 8.94 & 0.68 & 6.48 & 6.22 & 0.78 \\
\hline ECEC & 13.50 & 14.8 & 0.37 & 12.72 & 11.38 & 0.38 \\
\hline $\mathrm{Cu}\left(\mathrm{mg} \mathrm{kg}^{-1}\right)$ & 1.65 & 1.46 & 0.69 & 2.56 & 1.95 & 0.16 \\
\hline $\mathrm{Zn}\left(\mathrm{mg} \mathrm{kg}^{-1}\right)$ & 6.91 & 7.64 & 0.56 & 7.81 & 8.89 & 0.53 \\
\hline $\mathrm{Fe}\left(\mathrm{mg} \mathrm{kg}^{-1}\right)$ & 745.82 & 523.05 & 0.49 & 678.30 & 744.96 & 0.82 \\
\hline $\operatorname{Mn}\left(\mathrm{mg} \mathrm{kg}^{-1}\right)$ & 737.78 & 443.83 & 0.45 & 273.18 & 285.71 & 0.93 \\
\hline $\mathrm{T} \% \mathrm{~N}(\%)$ & 0.06 & 0.03 & 0.20 & 0.07 & 0.04 & 0.07 \\
\hline Org. C (\%) & 1.42 & 0.42 & 0.18 & 1.54 & 0.81 & 0.02 \\
\hline $\mathrm{pH}$ & 6.24 & 6.41 & 0.30 & 5.98 & 6.05 & 0.47 \\
\hline EA & 0.60 & 0.65 & 0.90 & 0.55 & 0.74 & 0.55 \\
\hline $\mathrm{P}\left(\mathrm{mg} \mathrm{kg}^{-1}\right)$ & 2.43 & 3.16 & 0.40 & 2.63 & 2.46 & 0.70 \\
\hline Sand (\%) & 74.92 & 75.8 & 0.95 & 59.03 & 57.35 & 0.76 \\
\hline Clay (\%) & 6.76 & 12.23 & 0.28 & 12.67 & 16.92 & 0.10 \\
\hline Silt (\%) & 18.32 & 11.97 & 0.56 & 28.30 & 25.78 & 0.53 \\
\hline
\end{tabular}

Difference between means is significant at $\mathrm{p}(<0.05)$. 
Table $2 \mathrm{~b}$. The physical and chemical properties of the topsoils and subsoils of the Colluvial parent materials. Figures are mean values for sampled horizons

\begin{tabular}{|c|c|c|c|c|c|c|}
\hline \multirow[t]{2}{*}{ Soil Properties } & \multicolumn{3}{|c|}{ Colluvial Parent Materials (Basement) } & \multicolumn{3}{|c|}{ Colluvial Parent Materials (Sedimentary) } \\
\hline & $\begin{array}{c}\text { Topsoil } \\
(\mathrm{n}=5)\end{array}$ & $\begin{array}{c}\text { Subsoil } \\
(\mathrm{n}=16)\end{array}$ & F-value & $\begin{array}{c}\text { Topsoil } \\
(\mathrm{n}=3)\end{array}$ & $\begin{array}{c}\text { Subsoil } \\
(\mathrm{n}=6)\end{array}$ & Sig.value \\
\hline $\mathrm{Ca}\left(\mathrm{cmol} \mathrm{kg}^{-1}\right)$ & 4.43 & 4.72 & 0.79 & 3.98 & 4.01 & 0.97 \\
\hline $\operatorname{Mg}\left(\mathrm{cmol} \mathrm{kg}^{-1}\right)$ & 0.15 & 0.14 & 0.77 & 0.16 & 0.17 & 0.79 \\
\hline $\mathrm{K}\left(\mathrm{cmol} \mathrm{kg}^{-1}\right)$ & 0.38 & 0.31 & 0.11 & 0.29 & 0.32 & 0.52 \\
\hline $\mathrm{Na}\left(\mathrm{cmol} \mathrm{kg}^{-1}\right)$ & 7.13 & 7.70 & 0.36 & 9.29 & 7.43 & 0.07 \\
\hline ECEC & 12.40 & 13.44 & 0.48 & 14.15 & 12.89 & 0.36 \\
\hline $\mathrm{Cu}\left(\mathrm{mg} \mathrm{kg}^{-1}\right)$ & 1.88 & 1.93 & 0.93 & 2.57 & 2.98 & 0.61 \\
\hline $\mathrm{Zn}\left(\mathrm{mg} \mathrm{kg}^{-1}\right)$ & 8.10 & 9.04 & 0.62 & 6.91 & 12.25 & 0.23 \\
\hline $\mathrm{Fe}\left(\mathrm{mg} \mathrm{kg}^{-1}\right)$ & 394.30 & 932.13 & 0.34 & 799.88 & 479.90 & 0.35 \\
\hline $\operatorname{Mn}\left(\mathrm{mg} \mathrm{kg}^{-1}\right)$ & 345.54 & 240.46 & 0.46 & 196.53 & 108.78 & 0.31 \\
\hline $\mathrm{T} \% \mathrm{~N}(\%)$ & 0.05 & 0.03 & 0.02 & 0.07 & 0.04 & 0.25 \\
\hline Org. C (\%) & 1.74 & 0.48 & 0.02 & 0.81 & 0.65 & 0.46 \\
\hline $\mathrm{pH}$ & 6.61 & 6.52 & 0.46 & 5.91 & 6.13 & 0.03 \\
\hline EA & 0.30 & 0.54 & 0.18 & 0.43 & 0.96 & 0.36 \\
\hline $\mathrm{P}\left(\mathrm{mg} \mathrm{kg}^{-1}\right)$ & 2.80 & 3.35 & 0.62 & 3.01 & 3.09 & 0.89 \\
\hline Sand (\%) & 78.48 & 79.89 & 0.74 & 54.60 & 50.50 & 0.69 \\
\hline Clay (\%) & 9.44 & 9.07 & 0.85 & 12.40 & 17.50 & 0.20 \\
\hline Silt (\%) & 12.08 & 11.19 & 0.80 & 33.00 & 32.00 & 0.90 \\
\hline
\end{tabular}

Difference between means is significant at $\mathrm{p}(<0.05)$.

\subsection{The Effects of Slope Positions on Soil Properties}

The effect of slope position on soil properties is of great importance in soil suitability assessment as it plays significant role in the vertical and lateral pedogenic-geomorphic processes along the catenas. The analysis of the variations in the amount and concentration of topsoil and subsoil properties at the three slope positions shows some contrasting results (Table 3). The amount of organic carbon is significantly different between topsoil and subsoil horizons at the three slope positions. It was higher at the topsoils than the subsoils. This indicates the role of soil leaching and movement of materials downslope as contributory factors. The other soil properties were not influenced by the different slope positions along the catenas due largely to the fact that similar vertical pedogenic-geomorphic processes affected the concentration of these topsoil and subsoil properties. It also affirms that the soils are similar in parent material composition. But a comparison of soil profiles in the catenas of the study sites without consideration for variations in soil depth indicates that $\mathrm{K}, \mathrm{Fe}$, Org. C and EA are significantly different along the catenas. 
Table 3. Physical and chemical properties of the basement complex and sedimentary rocks at different slope positions. Figures are mean values for sampled horizons

\begin{tabular}{|c|c|c|c|c|c|c|c|c|c|c|c|c|c|}
\hline \multirow[t]{2}{*}{ Soil Properties } & \multicolumn{7}{|c|}{ Basement Rocks } & \multicolumn{4}{|c|}{ Sedimentary Rocks } & \multirow[b]{2}{*}{$\begin{array}{l}\text { M6 } \\
(n=2)\end{array}$} & \multirow[b]{2}{*}{ Sig.value } \\
\hline & $\begin{array}{l}\mathrm{Y} 1 \\
(\mathrm{n}=6)\end{array}$ & $\begin{array}{l}\mathrm{Y} 2 \\
(\mathrm{n}=5)\end{array}$ & $\begin{array}{l}Y 3 \\
(n=5)\end{array}$ & $\begin{array}{l}\mathrm{Y} 4 \\
(\mathrm{n}=5)\end{array}$ & $\begin{array}{l}\text { Y5 } \\
(n=6)\end{array}$ & $\begin{array}{l}\text { Y6 } \\
(n=5)\end{array}$ & $\begin{array}{l}\text { M1 } \\
(n=6)\end{array}$ & $\begin{array}{l}\text { M2 } \\
(n=5)\end{array}$ & $\begin{array}{l}\text { M3 } \\
(n=4)\end{array}$ & $\begin{array}{l}\text { M4 } \\
(n=7)\end{array}$ & $\begin{array}{l}\text { M5 } \\
(n=4)\end{array}$ & & \\
\hline $\mathrm{Ca}\left(\mathrm{cmol} \mathrm{kg}^{-1}\right)$ & 4.47 & 3.99 & 2.04 & 4.58 & 6.49 & 5.71 & 5.08 & 3.56 & 4.55 & 3.59 & 4.20 & 5.18 & 0.00 \\
\hline $\mathrm{Mg}\left(\mathrm{cmol} \mathrm{kg}^{-1}\right)$ & 0.13 & 0.12 & 0.08 & 0.15 & 0.18 & 0.20 & 0.15 & 0.15 & 0.18 & 0.12 & 0.16 & 0.18 & 0.00 \\
\hline $\mathrm{K}\left(\mathrm{cmol} \mathrm{kg}^{-1}\right)$ & 0.32 & 0.38 & 0.33 & 0.35 & 0.30 & 0.31 & 0.36 & 0.28 & 0.34 & 0.29 & 0.31 & 0.35 & 0.53 \\
\hline $\mathrm{Na}\left(\mathrm{cmol} \mathrm{kg}^{-1}\right)$ & 9.27 & 7.78 & 6.53 & 7.84 & 8.19 & 7.64 & 7.61 & 8.45 & 7.55 & 5.19 & 6.28 & 6.32 & 0.02 \\
\hline ECEC & 14.91 & 12.72 & 9.48 & 13.41 & 15.77 & 14.29 & 13.94 & 12.98 & 13.72 & 9.58 & 12.00 & 12.77 & 0.00 \\
\hline $\mathrm{Cu}\left(\mathrm{mg} \mathrm{kg}^{-1}\right)$ & 1.90 & 1.07 & 1.35 & 1.12 & 2.28 & 2.88 & 2.40 & 2.32 & 3.50 & 1.64 & 2.62 & 2.14 & 0.00 \\
\hline $\mathrm{Zn}\left(\mathrm{mg} \mathrm{kg}^{-1}\right)$ & 7.30 & 5.46 & 7.74 & 7.33 & 11.55 & 9.96 & 9.73 & 8.40 & 13.06 & 7.53 & 9.67 & 6.30 & 0.08 \\
\hline $\mathrm{Fe}\left(\mathrm{mg} \mathrm{kg}^{-1}\right)$ & 896.7 & 1659.3 & 296.1 & 297.5 & 449.0 & 882.9 & 876.0 & 500.9 & 693.6 & 518.2 & 522.6 & 1390.2 & 0.15 \\
\hline $\operatorname{Mn}\left(\mathrm{mg} \mathrm{kg}^{-1}\right)$ & 919.8 & 455.4 & 134.4 & 166.6 & 181.2 & 307.8 & 318.9 & 89.8 & 198.3 & 274.9 & 101.9 & 553.4 & 0.00 \\
\hline $\mathrm{T} \% \mathrm{~N}(\%)$ & 0.06 & 0.06 & 0.03 & 0.03 & 0.03 & 0.03 & 0.05 & 0.06 & 0.05 & 0.04 & 0.05 & 0.11 & 0.03 \\
\hline Org. C (\%) & 1.05 & 1.47 & 0.35 & 0.66 & 0.57 & 0.79 & 1.35 & 0.79 & 0.61 & 0.60 & 0.88 & 2.03 & 0.25 \\
\hline $\mathrm{pH}$ & 6.18 & 6.42 & 6.49 & 6.51 & 6.58 & 6.68 & 5.99 & 6.02 & 6.13 & 6.13 & 5.98 & 5.93 & 0.00 \\
\hline EA & 0.75 & 0.46 & 0.50 & 0.48 & 0.61 & 0.42 & 0.73 & 0.54 & 1.1 & 0.40 & 1.05 & 0.75 & 0.72 \\
\hline $\mathrm{P}\left(\mathrm{mg} \mathrm{kg}^{-1}\right)$ & 2.07 & 2.17 & 1.24 & 3.74 & 5.15 & 3.93 & 2.52 & 3.25 & 2.83 & 2.38 & 2.43 & 3.11 & 0.00 \\
\hline Sand (\%) & 64.27 & 77.72 & 80.64 & 88.76 & 77.27 & 83.04 & 50.03 & 55.72 & 47.05 & 67.66 & 51.35 & 60.30 & 0.00 \\
\hline Clay (\%) & 13.23 & 9.80 & 7.80 & 5.56 & 9.77 & 9.16 & 17.10 & 15.64 & 16.00 & 12.97 & 19.40 & 12.50 & 0.00 \\
\hline Silt (\%) & 22.50 & 12.48 & 12.04 & 5.68 & 12.97 & 7.80 & 32.87 & 28.64 & 36.95 & 19.41 & 29.35 & 27.20 & 0.00 \\
\hline
\end{tabular}

Difference between means is significant at $\mathrm{p}(<0.05)$

\section{Some Implications of the Study}

The role of lithology and geomorphic processes on the differences of soil properties among different parent materials have been reported in similar results. Salako (2006), for example, observed that geomorphic processes and parent materials do have different influences in the concentrations of soil chemical properties especially the cations between sites of different parent materials. Olowolafe (2002) also established some differences in soil chemical properties due to the influence of soil parent materials in a study of two separate catchment areas of Jos, Nigeria. The implications of this for soil management practices and crop regimes in the area cannot be over-emphasized. For instance, since soils formed from the same parent material have the same amount and concentration of soil properties irrespective of soil depth and ecological zone, it is only logical to conclude that by ensuring the protection and/or enhancement of the parent material could guarantee the quality of the soils. Also, land improvement practice through treatment and remediation of soils becomes possible, easier and cheaper at source. It is also plausible to add that crops could enjoy similar supply of nutrient irrespective of their diverse root depth and ecological requirements.

The fact that soil properties were not very sensitive to variations in elevations from the higher portion of the study area to the lower end implies the differences in soil characteristics were more associated with the vertical than lateral movements despite the heterogeneous nature of the landscape. Zueng-Sang et al. (1997) reported similar influence of slope-related processes on variability of soil properties in southern Taiwan. A possible explanation for this may not be unconnected with differences in weathering, transportation and deposition history and processes of the minerals and rocks from where these soils were derived which cannot be overlooked in soil use and management. It is therefore possible to grow similar crops in different sections of the landscape and deploy similar management techniques for soil management and get the same results.

It will however be pertinent in the future to use experimental plots to verify these results since presently there are more heterogeneous crops grown in the study area. Moreover, it will be worthwhile to examine water movement 
and residency to depict the soil hydrology to verify the soil moisture regimes and soil classifications in a study of this nature which could even be possibly linked to climate change.

\section{Conclusions}

The study has demonstrated the relevance of landscape analysis and evaluation in soil and land use management. The role of lithology, parent materials and slope positions on pedo-geomorphic factors and processes and their implications for topsoil and subsoil properties have been reported. The soils of the study area have more heterogeneous properties within individual rock formations, parent materials and slope positions than between them. This emphasizes the predominance of vertical more than the lateral pedogenetic-geomorphic factors and processes as established in other studies enumerated above. The heterogeneous nature of rock formations, parent materials and slope positions of the studied catenas seems to have little or no influence on the variations of topsoil and subsoil properties. However, it demonstrates that catenas on two distinct parent rock types and ecological zones with vertical and lateral variations in factors and processes may display unique patterns of intra-and inter-catenary variations of the topsoil and subsoil properties. This suggests that the soils are genetically linked due to the influence of relief such as different elevations and slope positions in the landscape and geomorphic factors such as parent materials which affirms catenary associations of soils along the hillslopes.

\section{References}

Ahn, P. M. (1979). West African Soils. Oxford, United Kingdom: University Press.

Areola, O. (1984). The characteristics and fertility status of the old cocoa farms of Ibadan region, Nigeria. Malaysia Journal of Tropical Geography, 10, 1-11.

Black, C. A. (1965). Methods of Soil Analysis. Agronomy No. 9 Part 2. Madison, Wiscosin, USA: American Society of Agronomy.

Bray, R. H., \& Kurtz, L. T. (1945). Determination of total organic and available forms of phosphorous in soils. Soil science, 59, 39-45. http://dx.doi.org/10.1097/00010694-194501000-00006

Elliot, E. T., Heil, J. W., Kelly, E. F., \& Monger, H. C. (1999). Soil Structure and other Physical Properties. In Robertson, G. P., Coleman, D. C., Bledsoe, C. S., Collins, P., \& Sollins, P. (Eds.) Standard Soil Method for Long-Term Ecological Research (pp. 74-85). New York, USA: Oxford University Press.

FAO. (2006). Guidelines for Soil Description (4th Edition). Italy, Rome: Food and Organization of the United Natiuons.

Hammer, R. D., O'Brien, R. G., \& Lewis, R. J. (1987). Temporal and spatial soil variability on three forested land types on the Mid-Cumbreland Plateau. Soil Science Society America Journal, 51, 1320-1326. http://dx.doi.org/10.2136/sssaj1987.03615995005100050041x

IUSS Working Group WRB. (2006). World Reference Base for Soil Resources 2006. Italy, Rome: FAO World Soil Resources Reports No. 103.

Jenkinson, Byrun Jeremiah. (2002). Hydrology of Sandy Soils in South West Indiana and Ironoxide Indicators to identify Hydric Soils. PhD Thesis, Purde University, Indiana, USA.

Juo, A. S. R. (1975). Selected methods for soil and plant analysis. Nigeria: Ibadan. IITA Manual series 1.

Juo, A. S., Moormann, F. R., \& Maduakor, H. O. (1974). Forms and pedogenetic distribution of extractable iron and aluminum in selected soils of Nigeria. Geoderma, 11, 167-229. http://dx.doi.org/10.1016/0016-7061(74)90015-9

Mclean, E. O. (1965). Aluminium. In: Methods of soil analysis (ed. C.A. Black): 978-998. Agronomy No. 9. Part II. America Society of Agronomy, Maidson.

Moss, R. P. (1957). Classification of Soils found Over Sedimentary Rocks in Western Nigeria. Soil Survey Report No. 67. Nigeria, Ibadan: Ministry of Agriculture and Natural Resources.

Munsell Colour Company. (1975). Munsell Soil Colour Charts, USA, Baltimore, MD: Munsell Colour Company.

Ogun-Ogun River Basin Development Authority (OORBDA). (1982). Ogun River Basin Feasibility Report, Volume 7. Nigeria, Ibadan: Tahal Consultants (Nig.) Limited.

Ogun-Osun River Basin Development Authority (OORBDA). (2006). Unpublished Meteorological Laboratory Results, Abeokuta 
Ogunwale, \& Ashaye. (1975). Sandstone-derived Soils of a Catena at Iperu, Nigeria. Nigeria, Ibadan: Institute of Agricultural Research and Training, Moor Plantation, University of Ife, Nigeria.

Ojanuga, A. G. (1981). Soil Study in the Forest-Savanna Ecotone Region of Nigeria. Nigeria Journal of Soil Sciences, 1, 29-46.

Olowolafe, E. A. (2002). Soil parent materials and soil properties in two separate catchment areas on the Jos Plateau. Geoderma, 56, 201-212. Retrieved from http://www.jstor.org/stable/41147686

Reese, R. E., \& Moorhead, K. K. (1996). Spatial characteristics of soil properties along an elevational gradient in a Carolina Bay. Soil Science Society America Journal, 60, 1273-1277. http://dx.doi.org/10.2136/sssaj1996.03615995006000040045x

Salako, K. F., Tian, G., Kirchhof, G., \& Akinbola, G. E. (2006). Soil Particles in agricultural landscapes of derived savanna in southwestern Nigeria and implications for selected soil properties. Geoderma, 137(1-2), 90-99. http://dx.doi.org/10.1016/j.geoderma.2006.06.017

Smyth, A. J., \& Montgomery, R. F. (1962). Soils and land use in central western Nigeria. Nigeria, Ibadan: Government Printer.

Soil Survey Staff. (1999). Soil Taxonomy, A basic system of soil classification for making and interpreting soil surveys (2nd ed.). Agricultural Handbook No. 436. USA, Washington, D.C.: Natural Resources Conservation Service, USDA.

Soil Survey Staff. (2003). Keys to Soil Taxonomy (9th ed.). USA, Washington, D.C.: Natural Resources Conservation Service, USDA.

Soil Survey Staff. (2006). Keys to Soil Taxonomy (10th ed.). USA, Washington, D.C.: Natural Resources Conservation Service.

SPSS. (2003). SPSS for Windows. Release 12.0. Chicago, USA: SPSS Incorporated.

Torrent, J., Schwetmann, U., Fechter, H., \& Alferez, F. (1984). Quantitative relationships between soil colour and hematite content. USA, Baltimore MD. Soil Science, 136, 354-358. http://dx.doi.org/10.1097/00010694-198312000-00004

Walkley, A., \& Black, I. A. (1934). An Examination of the method for determining soil organic content matter and proposed modification of chromic acid titration method. Soil Science, 37, 29-38. http://dx.doi.org/10.1097/00010694-193401000-00003

Zeng-Yei Hseu, \& Zueng-Sang Chen. (2001). Quantifying Soil Hydromorphology of Rice-Growing Ultisol Toposequences in Taiwan. Soil Science Society of America Journal, 65(1), 270-278. http://dx.doi.org/10.2136/sssaj2001.651270x 